\title{
The Extension of Cultural Dominance in Iran with the Establishment of New Schools in Ghajar Period
}

\author{
Mohammad Piri ${ }^{1}$ \\ ${ }^{1}$ Sistan and Baluchistan University, Iran \\ Correspondence: Mohammad Piri, Sistan and Baluchistan University, Iran. E-mail: \\ esfehani.mohamad3@gmail.com
}

Received: October 13, 2015 Accepted: November 18, 2015 Online Published: April 26, 2016

doi:10.5539/ies.v9n5p173

URL: http://dx.doi.org/10.5539/ies.v9n5p173

\begin{abstract}
Since the beginning of 19th century, England for political reasons tried to make relations with Iran. Englishmen besides political tricks tried to establish their trace in Iran society by cultural permeation. European religious commissions who proceeded in different parts of the world since 19th century, though apparently had religious motivations, but they actually became grader of colonization. The aim of this text is to determine quality of establishing such schools and their function in extension of England s permeation which is performed with trend study and documentary methods and by using the content of itineraries, memories and other firsthand resources. This study showed: religious schools were a way of cultural permeation of England in Iran in Ghajar period. These schools not only by training Iranian teenagers in western method made them strange with their national culture and in some cases utilized graduates of these schools for their own objectives, but also, sometimes in competition with each other effected on creating social crisis.
\end{abstract}

Keywords: England, new schools, colonization, religious commissions, Ghajar

\section{Introduction}

A characteristic of educating system in 19th century was its exiting from church and religious entities domination across Europe and some countries. Unlike past that education was based on religion, the content of educational system was mostly based on empirical and technical sciences. In this period, a wide range of average class of society turned to literacy and educational system was grown based on nationalism thought.

In one hand a great part of European governing class with this excuse that new general educations enforced rebellious spirit in people and weakened the church and religion s position opposed it but this matter didn't affect in the growing trend of educational system (Ghasemi, 1998, p. 19). It was in the time when increasing growth of science, industries and production of mass of generative and industrial stuffs in countries like England, French, Germany and America, made unavoidable the exportation of generative stuffs outside the boundaries of these countries. This matter extended colonization dimensions and intensified colonization trend of undeveloped countries. Imperialists needed some markets to attract surplus of their productions and sources for providing raw and preliminary materials for their industries, then they knew the best solution for assuring their governance on other parts of the world to change believes and culture of under influenced regions. European countries in continuation of imperialism competitions, started wide measurements to permeate culturally in colonies and tried to stabilize their economic, political influence in these societies persistently and increasingly.

This article tends to England measurements for creating new educational centers in Iran and tries to survey this country s hidden purposes by extending new schools in Iran.

\section{The Role of Religious Commissions in Enhancement of Exploiting Colonies}

The effective method which was utilized by imperial forces for extending their influence in colonies was dispatching missioners to these countries, so that from the beginning of exploratory journeys of Diaz and Vascudogama, Christianity propagation was propounded among people in occupied countries was promulgated. Pontiff, too, declared the provision of surrendering west and east lands to Spain and Portuguese, their protecting from dispatched Christian missioners to these regions and endeavoring to Christianize people in their under influence lands. In $922 \mathrm{AH} / 1516 \mathrm{AD}$ cardinal Ximenes ordered that Christian missioners too attend in campaigning that was performed to eastern and western lands and propagate Christianity in conquered regions 
(Haeri, 1989, p. 470).

Except Spain and Portuguese, other European countries also used religion instrument to extend their imperial influence scope. In this period, in addition to Catholics, also Protestants started their propagation activities in under influenced countries. With establishing western Indian company of Netherland in $1011 \mathrm{AH} / 1602 \mathrm{AD}$ dispatching of Christian missioners by the government support increased and a publication institution was also created in Florence to increase their advocates in under influence regions. Pontiff Grigory the thirteenth ordered western and eastern churches to herd with the aim propagating Christianity in Islamic world. To actualize this purpose, he ordered Florence publication institution to translate Arabic, Turkey, Persian and other western languages .After this order, missioners performed a wide effort to reach eastern manuscripts in different issues in countries like Iraq, Syria, Iran and India (Haeri, 1997, p. 474).

\section{The Presence of Western Missioners in Iran}

The extension of Iran s relations with western countries, familiarity and attention of Iranian to European culture, civilization and goods, occurrence of wars between Ira and Russia and Iran s involvement in international debates because of competition between European countries and also presence of some Christian factions in Iran, provided the ground for the presence of European missioners in Iran. Each of religious commissions tried to fixate their countries footsteps, by using the existence of various Christian fractions in Iran, attract them to one of catholic or protestant fractions. Armenian was the most important Christian fractions in Iran from whom the missioners tried to use as a means for propagating Christianity among Muslims (Walberger, 1990, p. 631).

England was one of the first countries that tried to use missioners for extending his imperial influence. One of individuals who had an important role in England imperial extension based on religion was Richard Hakluyt. In 991AH/1580 AD he went to Paris as special priest and England ambassador and there staged against benefits of French and Portuguese .Hakluyt wrote a book about the method of establishing imperial domination on other countries and tendered it to the first Elizabeth, England queen. The queen for the service he did granted him the income of Briton and Minister churches to keep this priest near her and consult him continually about imperial programs. One of noted tasks of Hakluyt in the field of England imperial influence extension was collecting tourism works and exploratory travels. This collection involved more than one and a half million words and included sees secrets and lands information to be used by imperial forces. Hakluyt believed that establishment of England domination in his colonies should be based on Christianity basis and confirmed that asserting Christianity to other nations without creating panic and pressure and except using military forces is a hard task (Haeri, 1988, pp. 478-479).

With the entrance of Henri Martin, a new term of English missioners in Iran started. Martin, after 5 years inhabitancy in India and learning Persian language in 1226-27 AH/1811-12 AD came to Iran and dwelled in Shiraz. He perched in contact with interior snoops along with Sir John Malcolm and Sir Goor Uzli, imperial agents. Martin s aim was Christianity propagation, weakening the base of Iranians religious beliefs and leading public and political and religious systems thoughts toward England benefits. According to existing reports, Martin during his 16 months inhabitancy in Iran performed these duties in the best possible form. He used the battle between Sufis and Rohanyon to weaken Iran s formal religion and tried to enfeeble the base of Islamic beliefs in benefit of Christianity (Kemble, 2005, pp. 9-12; Haeri, 1988, p. 525).

One of English commissionaires in Iran emphasized that: though English and American Christian missioners resided in Iran, but they were not allowed to Christianize anybody (Landor, 1388, p. 80). Such remarks with attention to Christian missioners professions and function don't seem so right. The objectives of Christian missioners are stated truly in these remarks of African people, where they shouted: At first we had lands and you holy book, now we have holy book and you held the authority of our land (Haeri, 1988, p. 507).

In 1256AH/140AD Mar Shimon requested England government to dispatch someone for providing a report of Nasturian status. And England government sent Dr. Bojerz to Iran. After presence in Iran and studying about Christian's status, he wrote a book about Iran s Nestorian beliefs (Kruzon, 1988, p. 690). These activities didn't last too much till $1286 \mathrm{AH} / 1869 \mathrm{AD}$ Robert Brous who had propagated for ten years among Panjab Muslims on behalf of church mission was dispatched to Iran. He tended to stay just one year in Iran, but his inhabitancy lasted two years. In $1288 \mathrm{AH} / 1871 \mathrm{AD}$, Brous decided to return to India but since 9 Muslims in Isfahan who had converted their religion requested him baptism, he increased his tarriance time again. Because of the risks that existed on behalf of missioners, Iran government in 1881 AD prohibited Muslims attendance in worships performance and their referring to Christian institutions. Although European missioners declared that they didn't accept the responsibility of these rules (Yeslon, 1989, p. 45).

English missioners in $1299 \mathrm{AH} / 1882 \mathrm{AD}$ began some measurements for restarting religious propaganda in Iran. 
In $1302 \mathrm{AH} / 1885 \mathrm{AD}$ an association was established in London to make contact with Iran s Nestorian. In 1303 $\mathrm{AH} / 1886 \mathrm{AD}$ two priests on behalf of this association to Iran and published a leaflet for Christian propagation but their activities didn't last so much in this stage too and indispensably in $1306 \mathrm{AH} / 1889 \mathrm{AD}$ they returned to their country (Nategh, 1368, p. 10).

British men in spite of their great influence in Iran tried less than French and America to influence in Iran through religious propagating. Though, we should confess that the first foreign missioners in Iran had English identity. The most important propagating instrument of missioners in Iran was creating school and hospital and performing welfare work, since in this way, they were able to contact with people and attract their attention (Sanjar, 1989, p. 19).

\section{Propagating Method of Foreign Christian Missioners in Ghajar Period}

The method of Christian missioners varied in different countries. According to culture, civilization, kind of living and the amount of enjoyment from social welfare of people in each country, they performed a special method for their propagating. But the main base of their propagation in poor and undeveloped countries was utilization of local people s poverty and distress. They established public institutions to use them in benefit of their religion and propagation and through these institutions made contact with people of these countries directly. In Ghajar period despite of the old historical fund and golden culture of Iranian society, Iran had become a poor country that was managed with a conventional economy based on cultivation and animal husbandry with a primary method. In Iranian society of this period, there were no trace of social welfare, hygiene and public education and had a great distance with European countries that had passed Renaissance period and had entered a new stage of civilization and economic, cultural and social growth. Nevertheless, after a while Europeans concluded that they can't simply overcome Iranian culture and Christianize them (Bejamin, 1363, pp. 403-404). But, this matter didn't prevent continuation of western missioners activities and they tried in different ways to approach people.

One of effective ways was performing therapeutic activities since, while in European countries there were considerable improvements in the field of medical sciences and Europeans had extirpated many diseases by vaccination but in poor countries like Iran, because of the prevalence of various diseases everyday many people were dying. So that in $1288 \mathrm{AH}$, cholera caused many people to die (Ravkazaki, 1986, p. 29, p. 42). It was in such a situation that Iranians for saving their lives knocked any door, among them, they asked help of foreign medical and sanitarian institutions. Foreign missioners likewise by using this status, as doctors acceded into houses and even Shah s seraglio and totally those missioners who worked as doctors and didn't interfere in religious affairs were more successful in Iran (Benjamin, 1984, 423). Of course Iran s Rohaniat didn't stayed silent so that at the time of cholera prevalence in Tehran in the course of distributing medicines, performed some propagations, they declared that the presence of foreigners had caused descending of disaster (Bell, 1984, pp. 52-53).

One of the centers which had medical activities in Iran was the house of San Vansan Doupaul sisters that was established by a number of hermit sisters in Tehran, Isfahan, Tabriz and Orumieh. With serving to poor, they tried to spread French influence and power and besides doing educational activities, attended in taking care of the sick. This institution received one thousand and five hundred Frank as help from Shahannually and in spite of this matter, they cared more about curing Europeans and Christians than Muslims, but they accepted all people regardless of their religion and beliefs in their remedial center (Urasel, 1974, pp. 111-112) and regarding lack of new medical science before establishment of Daralfonoon in Iran, many people referred to San Vansan Dupol sisters institution in cases like surgery, dentistry and midwifery (Sorna, 1984, p. 187). Missioners also marked establishing hospitals and in 1299 AH/1893AD Americans built a hospital in Orumieh (Elder, 1954, p. 25). They built the second hospital in 1311 AH/1893AD under supervision of Dr. Vishard in Tehran. This hospital besides curing the sick, attended in medical educating (Elder, 1954, pp. 43-44). In Naseraddin Shah Period, Americans established some hospitals in Hamadan and Tabriz.

\section{Iran's Educational System in Ghajar Period}

In Ghajar period, education among common people was in a low level and schooling was mostly under the authority of high level individuals. These people mostly paid attention to learning and reading Koran and Persian literary works and didn't try to establish new schools and training teachers and creating educational spaces in society. One of high ranking missions of Britain with pointing to Iran s educational system shortages writes: "if I had necessary authorities in Iran, instead of sending Iranians in groups to west for education, established some schools in Iran" (Krozon, 1991, p. 636).

This remark is in opposite of Sir Goor Uzly England minister Plenipotentiary in Iran. Uzly is the person who 
wrote to English foreign minister: "Iran should stay in disability and bestiality." He was formal mission on behalf of the third Gorge king of England to associate Iran as much as possible to England imperialistic politics and beggar this country in political, economic, cultural and scientific fields and devastate its physical and virtual funds (Haeri, 1988, p. 520). This dissension mostly refers to difference between England foreign minister agents and India generalissimo s point of view. English government was mostly proponent of using diplomacy and India generalissimo was advocate of using violence and military forces. However, it seems that they had been concordant in dispatching of missioners. Close link between English missions and formal agents of Christianity by both political systems clearly indicates their common willing and church's goal and England political system collection.

Despite of poverty in educational system, according to remarks of some European missions and visitors who had visited Iran, a considerable group of Iranians had been educated though in a low level. One of these European writes: "this vision that Iranians are illiterate is wrong. And also if we imagine that common Iranians have been fully educated, it is wrong too. It is better to say that average Iranians have been educated in spite of ignorance and better to say on average most Iranians have been educated, but if what people learn is education, average Iranians are more educated than Europeans, but educations are different. We can hardly find a quite ordinary Iranian in one of Iran s cities who can't read, he is somewhat able to read. Most people both can write to some extent and can perform mathematical calculations a little" (Landor, 2009, 136). Before constitution, there were two kinds of educational systems in Iran. One grope were schools that attended educating religious sciences and the other were isms where children learned reading and writing. In schools where theology studied for mastering, grammar, Arabic, logic, philosophy, doctrine, Jurisprudence and so on were taught and these schools was very prosperous and prevalent. But in isms nobody sent their children except grandee, wealthy people and tradesmen and these people were just satisfied with reading and writing that was useful for their job in market. In these schools, the students were first taught the alphabet and then short suras of the end of Koran. After that they gradually read the whole of Koran and in the last stage of education they learned reading of works like Golestan, Jame Abbasi, Nassab and Trasol, Abvab Janan, Nader history and Mojam history one after another (Kasravi, 1991, p. 19, p. 21).

One of English missions about education system in Ghajar period writes: "in Iran the task of educating is the responsibility of Ecclesiastical and like European religious schools teachers they also prefer religious educations to other kinds of educations. These educations are to the extent to provide their everyday needs. They do a little summation and subtraction calculations and memorize some poems and Koran ayahs. In great cities, the schools provide wider educations. The schools are usually built near mosques and it is completely at the authority of herdsmen. These schools are similar to university and they are managed quite conventional and mostly wealthy people s children study there. Children of these people spend all their time in learning medicine, law, religious lessons, literature and art. New schools of European and semi European type also exist in Iran. Generally, education status in Iran is excellent (Landror, 2009, pp. 136-137).

In Ghajar period in every city and village there were some kind of schools or isms under the supervision of herdsmen. Some of people who were studying in these schools couldn't write. If someone had the ability to read and write, he was called with the title of Mirza. Medial educations with European style didn't exist and most applicants were studied in three courses of science, jurisprudence and medicine... Expenses of these schools were also provided through devotion. Maarif minister didn't dominate on these schools and the schools incomes were in the hand of herdsmen (Krozon, 2001, pp. 636-637).

Daralfonoon was the first Iranian school with new style that was created by efforts of Amir Kabir and support of Naseraddin Shah. In this educational institution, too, preliminary lessons were taught in Persian and Arabic languages by Iranian teachers. In higher stages, English, French, Germany and Russia languages, mathematics, medicine, chemistry, designing, drawing, mineralogy, geography, music and military lessons were taught. In this school, one English teacher also taught and the number of students who studied English was30. In geography maps were drawn from English maps and pictorial books of England primary schools were taught. Also, they used the stories of Robinson Krozo and Baron Mon Hosen for translation (Krozen, 2001, p. 639).

\section{The Establishment of European Schools in Iran}

The first educational activity in new style in Iran started by Christian missioners. The first foreign school in Iran was created by Frenchmen in 1245 AH/1829AD in Tabriz and Kamran Mirza sent 10 students to this school for education (Lusoer, 1989, p. 85). In this year, Americans too, sent Esmit Woodwith to Iran. With the encouragement of these two, Juostine Perkens in 1259 AH/1836AD was sent to Iran. This group created Protestant church, clinic, library and a publication place to publish religious books in Orumieh and started to 
collect information all over Iran in assistance with other European missioners. They acquired wide information about economy and commercial goods required in Iran and the country s mineral sources and sent to united state along with their experiences and amylases of Iranian religious and cultural status (Deldam, 1979, p. 9).

Since this school was threatened by Muslims, Perkinz tried to achieve an order from Mohammad Ali Shah in approval of the school establishment through support of Prince Malek Ghasem Mirza. After receiving this order, Perkinz formally established his school in Sir Village. Gradually, American schools were spread in Iran so that the number of these schools reached 58 schools in which 2410 children were studying (Ghasemi, 1998, p. 514; Mahbooni, 1975, p. 241).

Frenchmen too tried to extend these institutions in Tabriz, Orumieh, Salmas, Isfahan and Tehran. Their aim from establishing these schools was to acquaint Iranian with European and French culture all over Iran. French men then selected Isfahan as their activities center (Dosarsi, 1983, p. 67).

Russian and German too, created some schools in Iran. With the extension of foreign schools in Iran, at first an intense competition between French and Americans was created for establishment of new schools and attraction of political and financial supports of Iran government. With the entrance of many Iranian children to these schools and the effort of Christian missioners for converting their religion, gradually their hidden goal of these schools and their sponsors for changing the mental and religious foundation of Iranians was revealed .But the element that saved the society from this danger, was consistent bases of Iranians beliefs and culture (Samie, 1997, p. 193). What more encouraged Europeans for propagating Christianity and western culture in Iran, was Bab uprising and gravitation of some of Iranians to this intellectual fraction. This same matter persuaded English religious commissions and other Europeans for creating educational and remedial centers (Krozon, 2001, p. 641).

\section{The Establishment of the First English Schools in Iran}

After failure of missioners in converting Iranian Muslims religion, influential and propagating politic of England government changed and they paid more attention to creating educational centers in Iran. One of English imperial agents points to this rotation as: "religious commissions in Iran performed admiring services but they couldn't Christianize Muslims. Just a number of orphans who were grown up in Christian schools were exceptions, the efforts of missioners in Iran was faced with heavy and impervious walls of Islam." He adds: "till Muslims know themselves pure surrender of God will and try to lead others to right way and know people who refuse God worship impious and admire martyrdom in the way of reaching God and heaven, spending much fortunes and sacrificing for extension of Christian thought quite useless." He knew evident propagation in this space the most useless task that missioners had performed in eastern lands and suggested: "missioners propagations should be performed none overtly and through non-religious affairs. Since this method reach us more than religious installations to our objectives. With school establishment and humanistic measurements especially providing free remedial assistances gradually and in an assured form, it is possible to pierce in people s hearts." (Krozon, 2001, p. 647).

After England s influential politic rotation, they placed the attraction of students in English schools as their caption of cultural invasion and so after French and Americans, started their educational and propagating activities in Christian regions of Azerbaijan. The first group of English church activists entered Orumieh in 1299 $\mathrm{AH} / 1882 \mathrm{ad}$. In $1304 \mathrm{AH} / 1887 \mathrm{AD}$, too, another group from Cambridge church came to this city for establishing a publication place and published a leaflet. They also created a boy and girl school in this region. But their activities in Azerbaijan were not successful, and then this group stopped their activities and came back to England (Ghasemi, 1988, p. 518).

After the entrance of English commissions to west of Iran, new priests were dispatched to this region in 1306 $\mathrm{AH} / 1888 \mathrm{AD}$. They exclaimed at the same beginning that their purpose was not Muslims attraction to Christianity but they meant to educate Nestorians who were dwelled in Iran s western regions especially Orumieh under the supervision of Kanan Mak Lin. This commission unlike past was treated well by Nestorians in these regions and found much influence. For this reason, they created a school for training priest educators in Orumieh. Soon this school was admired so that in 1306AH/1891AD 70students in boy school and 50 students in girl schools started educating there. After this success, English men created a school for priest sisters and an intermediate school in Suprgan and another one in Urdechay Orumieh in each of them 40 students were studying. English men totally crated 72 schools in Iran and Turkey villages that 1500 students were educating in them. In these schools 5 English missioners were also working and one of them was a priest named Brown. This missioner acquired one thousand Lire from membership right and nine hundred Lire for subsidy in 1307AH/1889AD (Krozon, 1988, p. 991). 


\section{The Spread of English Schools in Iran's Southern Regions}

The center of England educational activities in Iran s southern regions, as Isfahan, Kerman Yazd and Shiraz. Their activities increased after the entrance of Dr. Brus educational and religious missioner to Isfahan Jolfa in 1279AH/1862AD. English men, who politically competed acutely with Russian, performed a wide effort to extend their influence in Iran s southern regions. For extending their presence in this region, they tried to create some schools and promote western culture to strengthen their power roots. For this purpose English men started building several schools in the country s southern regions.

During near four hundred years passing from Armenia inhabitancy in Isfahan, various religious commissions belonging to other fractions of Christianity came to this city, but Armenia always emphasized on Orthodox dogma and was less influenced by missioners propagations. In some cases that the influence of missioners increased, they responded it. One of religious commissions that was not so successful in making close relations with Jolfa people was Lazarist fraction belonging to Catholic Church. The English Morsalin commission who couldn't find a suitable place among Armenian inhibitors of Jolfa, were indispensable to establish their welfare institutions and propagating centers out of this quarter and in other sectors of Isfahan. Lazarist commission in the late 19 century and beginning of 20 century was composed of 7 sisters under the supervision of a priest called Demote and their school in Jolfa had 80 boy and 115 girl students (Oben, 1983, p. 305).

The first English school in Isfahan was established by Brus about 1292AH/1875AD with the permission of Msood Mirza Zelosoltan. He named this school Masoodieh because of appreciation to Zelosoltan or fear of his coreligionist's invasion. In 1296AH/1879AD the number of students of this school reached 149 people. In this school they learnt Armenia, Persian and English languages. History, geography, general mathematics, algebra, geometry, natural philosophy (natural science) and astronomy were among other lessons of this school. 12 derelict students were keeping hostelry in this school. From these 149 students 51 persons were Armenian girls who were studying in a building separately. The girls besides learning lessons were busy with sewing, knitting and other handmade arts (Farhang newspaper, the first year, number 7, p. 1). Though Zelosltan issued the establishment of this school and went to visit it and awarded considerable helps to it (Safaie, 1970, p. 84), but since he decided to establish royal school, in a letter to Naseraddin Shah declared it existence harmful and wrote about Brus: in famine days, how much money he paid Isfahan people, now he has built a school and has taken a group of Armenia children under the title of science education to this school and has registered some of Armenians in London and each year take some of the to India and catch a letter for them from India deputy to be England national (Farhang newspaper, 1917, p. 1). Some other schools were also built in Isfahan.

After Dr. Brus in 1894 AD/1273H bishop Stewart entered Isfahan and moved the school from Jolfa to a house in Shirazi ha Chasugh quarter belonging to Aminosharieh. Of course the previous school in Jolfa was still active and later in its place Anoshirvan school was established. Bishop Stewart in 1911 AD/1290H LEFT Iran and in the same year died in England. After him, three persons named Elison, Waker and Linten became Adab school manager respectively. In 1913AD/1296H some money were sent for Isfahan bishopric bureau on behalf of England Morsalin commission. After that this school moved next to Shah Mosque (Imam Khomeini mosque) and then to its present place in front of Isfahan education organization. For appreciation of bishop Stewart services, reconstructed school was called Stewart memorial college (Ojen, 1977, p. 305, Isfahan Adab high school, 1328-1329, pp. 3-4).

Among other centers that were established in Isfahan by Morsalin fraction, religious commission dependent to England, was a girl school that was built in 1318 AH/1900AD. This commission established Doshizegan girl school that was later named AienBehesht. This school next to Logha church (beside present Isabn Maryam hospital) with the name of Persian girls school Isfahan started his work from 1279H/1900AD. Since the establishment of the school till $1927 \mathrm{H}$ all its teachers and managers were English. In this year, someone named Aydin whose mother was Irish and his father Armenia associated to this school as teacher and after a short while was selected as the schools manager. In $1938 \mathrm{H}$ an English teacher named Miss Iziccame to Iran who helped Miss Iaydin in managing and supervising Hostel and meanwhile taught English language.

After nationalizing petroleum industry, Isfahan people because of opposition of England with Mosaddegh government and sabotages of this country against Iran nation's will disgusted English men severely. English cultural institutions were not excluded from this suspicions and Behesht Aien and its manager was the object of mistrust and anger of people. For this reason, a great number of herdsmen unisonous with Isfahan Hozeh Elmieh with publication of a letter opposed to high school managing by Miss Iaydin and English teachers. This letter addressed culture minister as follows: all Isfahan people are quiet anguished and worry about educating status in girl high school Behesht Aien. manager of this high school is an English woman named Miss Iaydin who for 
several years has been responsible for secretive missions and helping his country by creating an indifference and colonist admiring environment that will lead to training Iranian mothers who are uninterested to country and religion and her presence in this crowd and important center would be dangerous and in future will be more than that. The account of a small sample of effects of this villainy factory was reflected in press two years ago. Moreover in it has no cultural meaning that in an Islamic city, training of Muslim girls to be under supervision of enemies of Iran and Islam in a national school. We request that immediately oust her and one erudite, patriot, nationalist Iranian Muslim lady to be substituted who cause weal and maintenance of mandates (Iran's national documents institution-Isfahan branch, file number 5309).

This open letter in addition to signature of 50 bodies of famous herdsmen was also signed by at least 20 physicians and a considerable number of merchants and children s parents and under mentioned statement name of very famous herdsman of that day, Mir Seid Hossein Charsughi was also observed who besides signing the letter had remarked so: Islamic country s culture! Either reverse or dissolve the first and second principles of constitution or close the door of this Aien hell that is center of atheism and prostitution and adultery. If there is someone in the house, one word is enough" (Reference 250).

After this request, a number of students started protecting the school s manager and some students and people asked exit of English people from the school. After such oppositions, the English manager was removed and Seid Mohammad Tadion who was one of Isfahan well known teachers became the school manager (Chehelstun newspaper, 1951, p. 4).

In Yazd too, the first girl school was established on behalf of Christian mission by an English woman named Nellie bright for Zoroastrian girls in 1282 AH1865AD. After a while, an English mistress "katemothersole" came to Yazd. But was afflicted with typhoid and died. In the First World Warall English people left Yazd and stayed in Tehran. In $1300 \mathrm{H}$ Mrs. Amnohi Iaydin came to Yazd on behalf of Christian mission, the aim of English schools in Yazd was exclaimed training of individuals with an open mind and good and lighthearted temper but in fact the meaning of open mind slogan had been receding from belief principles governing on Yazd society and acceptance of western culture and stabilization of England influence in Iran (Sadr, 1984, 175/3; Ghasemi, 1998, p. 537).

One of English commissioners who had visited that country s religious commission s schools in Yazd believed that these schools were far better than schools in England and the talent of Yazd children is higher than their students in England, so that a 6 years old child in Yazd solves matters that an English man 6 times older is not able to solve them. In his opinion transfer rate of an Iranian child s mind is amazing and with pointing to the England religious mission s school "Napir Malcolm", he continues: wealthy and propertied Muslims and a small number of Zoroastrians send their boys to this school and this is a good opportunity for teaching English. We should tank religious propagating association for building the school and establishment of good hospital that is built in Yazd. In this hospital one English doctor and 3 Armenia assistants are working constantly. In womenfolk's part also an English woman physician is working. The main duty of Yazd missioners is to Christianize people but this task is difficult. European employees of Yazd missionary center are educated for their mission. This center started their activities in 1898 AD BY Dr. Henry White. He had started his task as a doctor one year before in Isfahan Jolfa. In December of that year, Dr. Malkom associated him from England (Landor, 2009, pp. 275-278).

In Kerman the English religious missioners school was also created in 1339 AH/1921 AD. The expenses of this school were provided by this commission and other English welfare institutions. This school had 106 students from whom thirty students were educating free and the number of teachers was two. Boy Morsalin school of Kerman was also established by this commission and the expenses of this school were also paid by English welfare institutions. The school managers too were selected among English mission members (Ghasemipouya, 1998, pp. 537-538). The sponsors of these schools in the course of issuance of their culture and languages also tried to propagate Christianity. The content and method of education in these schools was also under the influence of doctrines of Christian religion (Dorani, 1999, p. 124).

Finally, in 1319 the government approved that all foreigners schools to be moved to culture ministry. Therefore, 4 schools that were managed under supervision of Morsalin religious mission (Steward memorial college, Behesht Aien in Isfahan, Mehr Aien in Yazd and Kerman school) in 28 Azar 1940 were possessed by government and according to existing document in the file of registry office, these four schools were purchased by Iran government with the price of 20 thousand Lire Esterling and 425000 Rials from bishop Williams James Stewart the manager of Stewart memorial college and supervisor of English Morsalin mission (Mir, 2001, p. 27). 


\section{The Competition of Western Religious Commissions in Iran}

Western religious commissions openly declared that their aim is to remove fetish thoughts and assistance to mental and economic status of their coreligionists in Iran and other countries of the third world. But their major and hidden aim was to extend their imperial influence in our country, for these reason gradually religious commissions of these countries stand affront of each other. From the beginning, there were jealousy and clash between American and English commissions. This disagreement was created for two reasons: one was that America came sooner and claimed that they own the patent of propagating in these regions and the other was that the aims of two American and English commissions were different (Korzan, 1988, p. 692). English men for extending their influence also went to other religious fractions like Jews. For this same reason, French Jew missioners had to compete with Christian missioners that were working on behalf of English men for attracting Jews and sometimes some conflicts happened between them (Ansari, 2000,95-99). Of course, Russians and Germans didn't show so much opposition with French educational activities (Losoer, 1989, p. 91). But after successes of French schools in Iran, English men opposed them apparently and hidden. In English men s opinion, any element that was not used in the way of stabilization of physical or moral success of Britain in Iran was their enemy and this insular and monopolizing mentality was considered one of characteristics of English employees who were serving in India colony. Here, French Law College, since England didn't have similar institution, was among educational centers that provoked English men $\mathrm{s}$ anger. Since they were afraid of French masters influence on young and intellectual class of Iran. For this reason, French men who dwelled in Iran were seen by English men not only as intruders but as dangerous rivals with whom they should conflict. It was with such a view that the ambassador of this country avoided from accepting the request of visiting French teachers of Iran Law College. In future, with England pressure, teaching of French language was omitted from Iranian school's curriculum in primary schools. These competitions were performed in different ways. They provided some facilities for more attracting teenagers to their institutions. Free classes for some students, distribution of free books and stationaries among students, creating employing opportunities for graduates in banks dependent to England and various office and military were among methods that English men used for attracting young people more. Also, in addition to propagating through their schools, periodically, they constituted conferences in Iran for declaring their culture (Losuer, 1989, pp. 92-94).

\section{Main Purposes of English with Creating Schools in Iran}

Studying of political events in recent centuries shows that some Christian missioners and priests who entered Iran and other countries of the third world, tried honestly for propagating Christianity and even lost their lives in this way. But this matter shouldn't cause that England educational and propagating commissions activities to be analyzed separate from imperial programs and wills of governors of this country. Some imperial agents of this country had confessed undesirably to impartibility of foreign politics of England and the aims of religious commissions of this country. One of these political officials about the influence of missionary, educational and political commissions that entered other countries writes:" if a little quinine and a little castor oil are used in one place, may be creates a situation through it worthy information is obtained that worth millions Lire for English government $\mathrm{s}$ rent. England nation should appreciate these devotees and pioneers. It is them that prepare tenacious bases for our empery that can be extended without fear (Landur, 2009, p. 378). In the same field, another English imperial agent who was dispatched to Sistan and Baluchistan boundaries declared: if some politicians know the presence of different political and economic commissions away from providing English government s rent, they are mistaken or it is due to their lack of knowledge from matters details. They usually misunderstand events (Kristi et al., 1999, pp. 253-254).

We should confess that widespread utilization of foreign teachers entailed that western educational programs and patterns open their way to Iran schools and through them a similar environment to Europe was created in Iran and European beliefs occupied the mind of Iranian student. One of English politicians suggests to that country s government:" to dominate on countries, we should change their beliefs.It is foolish to think that we can change religious beliefs and customs of millions Asian in one day. It is surprising that we, with a long precedent in imperial still hadn't reached this fact. The reason is that we can't detect habitudes and customs of people in these countries in our time. We have faced many harms from this and still it continues (Landur, 2009,143).

\section{Conclusion and Discussion}

The extension of imperialism in the world, altered destiny of many countries such as Iran. Western religious commissions departed orient to pave the way for imperialists and cultural invasion in the form of influencing in religious beliefs as a practical means was considered in European countries foreign politics. Iran was not excluded from this invasion and each religious commission who came Iran tried to propagate a fraction of 
Christianity. Since European countries were rivals in imperialistic objectives, conflict between religious commissions present in Iran increased and each one tried to find more advocates to provide their countries political and economic rent.

In 19th century, with increasing the competition between western countries, various commissions in rivalry with each other tried to attract a greater number of Iranians by creating schools, establishing hospitals and performing public works and since they had found that with belief in Islam propagating for Christianity wouldn't success in Iran, tried to organize a more effective cultural invasion by extending educational centers. It seems that English missioners though proceeded to establish schools later, was more successful than others. This country attracted the most talented Iranian teenagers by providing some facilities for them and sent them to India and Europe to continue their educations. English men by supporting postgraduates, who had been taught under the supervision of English teachers, employed them in various jobs inside and outside of the country for their own purposes.

Iranian society gradually reacted to measurements of missioners especially Morsalin English fraction. Herdsmen in every opportunity declared their opposition with foreigners' management in Muslim children training and also people distrusted sponsors and postgraduates of such schools. Accession of constitution movement and petroleum industry s nationalization motion caused a part of public dissatisfaction toward English educational institutions activities to become evident and finally, Iran government, after approving the law of conceding all foreign schools, under public thought pressure purchased the lands relating to Morsalin English fraction schools and awarded its management to Iranians.

\section{References}

Annals of Isfahan Adab high school. (1949-1950). Isfahan, Isfahan province education office (pp. 3-4).

Ansari, H. (2000). A preface on Isfahan sociology, with the effort of Ahmad Javaheri (1st ed.). Tehran, Naghsh e Jahan.

Bel, G. (1984). Images from Iran (translated by Bozorgmehr Riahi, 1st ed.). Tehran: Kharazmi.

Benjamin, S. G. (1984). Iran and Iranians (With the efforts of Rahim Reza Zadeh, 1st ed.). Tehran, Molk publications.

Cristy et al. (1999). Sistan geographical history, travel with logbooks (Translated by Hasan Ahmadi, 1st ed.). Tehran, Moalef publication.

Deldam, E. (1989). Haji Washington, Iran and America relation history in Ghajar and Pahlavi period. Tehran: Amin publication.

Diolafoia, J. B. (1990). Iran, Kaldeh, Shoosh (Translated by Ali Mohammad Frahvashi, with the efforts of Bahram Frahvashi, 1st ed.). Tehran: Tehran university publication.

Dorrani, K. (2008). Iran s education history before and after revolution. Tehran, Samt.

Dusrsi, K. (1983). Iran in 1839-1840 AD, strenuous ambassadorship of Dusarsi in Iran (Translated by Ehsan Eshraghi, 1st ed.). Tehran: Nashr e daneshgahi.

Elder, J. (1954). American missioners history in Iran (Translated by Soheil Azari, 1st ed.). Tehran: NoorJahan.

Ghasemi, P. (1998). New schools in Ghajar period. Tehran: Nashr Daneshgahi Center.

Haeri, A. (1988). The first confrontations of Iran s idealists with two procedures of western bourgeoisie civilization. Tehran, Amir Kabir.

Kambel, J. (2005). The two last years (1st volume, translated by Ebrahim Teimory). Tehran, Tehran university publication.

Kasravi, A. (1991). Iran constitution history (16th ed.). Tehran, Amir Kabir.

Krozon, J. N. (1988). Iran and Iran case (1st volume, translated by Golam, Ali Vahid Mazandrani). Tehran: Elmi and farhangi publication.

Landor, A. H. S. (2009). Iran's political, social, cultural, economic and commercial status in the beginning of constitution (Translated by Ali Akbar Abdorashidi, 1st ed.). Tehran: Etelaat.

Losoeor, E. (1989). England influence in Iran (Translated by Mohammad Bagher Ahmadi Tarshizi). Tehran: Publication of book for everybody.

Mahbobi, A., H. (1975). New civilized institutions history in Iran. Tehran: Tehran university.

Mir, E. et al. (2001). Genesis march of Isfahan Aien high school, memorial of $100^{\text {th }}$ year of Aien establishment 
Aban 1379. Isfahan, Isfahan province education office.

Nategh, H. (1988). Iran's Tarsian schools. Tehran: Dabireh publication, Behrooz Pajouheshassociation.

Ogen, O. F. (1977). Today Iran 1906-1907 AD (Translation and explanation by Ali Asghar Saiedi). Iran and Bahrolnahrein. Tehran: Zavar.

Orsel, E. (1974). Ernest Orsel itinerary (Translated by Ali Asghar Mofidi). Tehran: Zaver.

Ravkazaki, S. (1986). Famine in $1288 A H$ (pp. 29-41). Tehran: Ayandeh Magazine.

Sadr, H. M. (1984). Iran's press and leaflets history, with the preface of Hosein Sadr Hashemi. Isfahan, Kamal.

Safaie, E. (1960). New finding documents. Tehran, Babak, unmatched.

Samie, A. A. R. (1997). Schools evolutions history in Iran, Tehran, the publication of development and outfit of the country s schools organization.

Sanjar, E. (1989). America s influence in Iran. Tehran: Khsheh publication.

Sorna, K. (1984). People and ethics in Iran (Translated by Ali Asghar Siedi, 1st ed.). Tehran: Zavar.

Walderburg, A. (1990). German missioners in Iran (Translated by Ali Rahmani, foreign politic magazine, fourth year).

Yaslon, A. (1989). Political relations of Iran and America (Translated by Bagher Aram). Tehran: Amir Kabir.

\section{Copyrights}

Copyright for this article is retained by the author(s), with first publication rights granted to the journal.

This is an open-access article distributed under the terms and conditions of the Creative Commons Attribution license (http://creativecommons.org/licenses/by/3.0/). 